\title{
Yhdyspankin tukema lisensiaatti- ja tohtorikoulutus
}

\begin{abstract}
Lähtökohta
Suomen Yhdyspankki on 125-juhlavuotensa kunniaksi sitoutunut tukemaan taloustieteiden jatkokoulutusta Helsingin kauppakorkeakoulun ja Svenska Handelshögskolanin puitteissa. Tavoitteena on tehostaa talouselämän ja kauppakorkeakoulujen yhteistyötä ja lisätä merkittävästi taloustieteitten jatkotutkintojen määrää vuosittain.
\end{abstract}

\section{Pankin rooli}

Yhdyspankki toimii koulutuksen taloudellisena tukijana. Pankki on sitoutunut käyttämään tähän 1,5 mmk vuodessa vuosien 1987-1992 ajan. Pankin tuesta käytetään osa apurahoina opiskelijoille ja palkkioina opintojen ohjaajille. Tuesta maksetaan myös ulkomaalaisten professorien luentopalkkiot, intensiivikurssien järjestelykustannukset ja mahdollisesti opiskelijoiden osallistumismaksut kursseille ulkomailla.

\section{Tohtori- ja lisensiaattitutkinto}

Tutkintojen rakenne ja sisältö noudattavat kauppakorkeakoulujen virallisia tutkintovaatimuksia. Tutkinnon pääaineen tulee olla joku liiketaloustieteistä tai kansantaloustiede. Väitöskirja- ja lisensiaattityöt valitaan ensisijaisesti talouselämästä, mahidollisuuksien mukaan opiskelijan päivittäisen työn piiristä.

Pääaineeseen liittyvä opetus perustuu paljolti intensiivikurssien laajamittaiseen käyttöön. Kursseja järjestetään mahdollisuuksien mukaan kerran tai kaksi vuodessa kussakin aineessa. Korkeakoulujen normaaleja jatkokoulutuskursseja käytetään hyväksi.

Opinto-ohjelmat laaditaan yksilöllisesti ja opintoja ohjataan systemaattisesti. Työssäkäyvien opiskelijoiden työnantajilta hankitaan lupaus opintojen tukemisesta. Tavoitteena on tutkinnon suorittaminen 3-5 vuodessa.

\section{Opiskelijoiden valinta ja määrä}

Tuki on tarkoitettu kaikille nuorille kehitysky- kyisille jatko-opiskelijoille, joilla on mahdollisuus täysitehoiseen opiskeluun. Opiskelijat valitaan vuosittaisen valtakunnallisen avoimen haun perusteella. Valintakriteerinä on yleinen soveltuvuus, johon vaikuttavat mm. lahjakkuus, motivaatio ja opintosuunnitelman realistisuus. Työkokemus elinkeinoelämästä lasketaan eduksi.

Vuosittain otetaan 5-10 uutta opiskelijaa. Tavoitteena on vähintään 5 tutkintoa vuodessa.

Yhdyspankki tarjoaa vuosittain muutamalle työntekijälleen mahdollisuuden jatko-opiskeluun tämän ohjelman puitteissa. Tavoitteena on saada myös muut yritykset tekemään samoin. Tämä edellyttää, että opiskelijat saavat työnantajaltaan palkallista opintoaikaa, varoja välittömien tutkimusmenojensa kattamiseen ja mahdollisesti tukea internaattikulujen maksamiseen.

\section{Organisaatio}

Ohjelmaa hoidetaan ensisijaisesti Yhdyspankin, Helsingin kauppakorkeakoulun ja Svenska Handelshögskolanin voimin. Tarvittaessa kytketään mukaan myös muiden yritysten ja korkeakoulujen edustajia.

Pankin tuen käytöstä ja tarvittavista yhteyksistä talouselämään vastaa seurantaryhmä, jonka jäseninä ovat pääjohtaja Mika Tiivola ja toimitusjohtaja Ahti Hirvonen Yhdyspankista, kansleri Jaakko Honko ja rehtori Arvi Leponiemi Helsingin kauppakorkeakoulusta ja rehtori Alf Lerviks Svenska Handelshögskolanista.

Ohjelman sisällöstä, opiskelijoiden rekrytoinnista ym. vastaa johtoryhmä, jonka puheenjohtajana on pankinjohtaja Björn Wahlroos. Jäseninä ovat professorit Fedi Vaivio, Aarni Nuberg ja Markku Kallio HKKk:sta, professori Johan Fellman SHH:sta ja pankinjohtajat Eero Pynnönen ja Esko Kervinen SYP:sta.

Ohjelman johtaja on Markku Kallio ja pankin puolelta vastuuhenkilö on pankinjoht. Esko Kervinen. 